\title{
臨床研究
}

\section{当院における胆膵内視鏡検査時の 呼吸循環器系合併症に対するリスクマネージメント}

\begin{tabular}{|c|c|c|c|}
\hline 岩崎栄典1)* & 福原誠一郎 ${ }^{2)}$ & 松永崇宏1) & 町田雄二郎 ${ }^{1)}$ \\
\hline 澈本洋一1) & 玉川空樹1) & 片山 正 ${ }^{1)}$ & 一洋1) \\
\hline 慎太郎 ${ }^{1)}$ & 清野隆史 ${ }^{1)}$ & 松下美沙子 ${ }^{1)}$ & 昌靖1) \\
\hline 直樹2) & 北郷＼cjkstart実3) & 緒方晴彦2) & 金井隆 \\
\hline
\end{tabular}

要約 : 胆膵内視鏡は処置時間が長いことから, 安定した処置を実現するために, 鎮静を深 く設定する必要がある．さらに，高齢者や全身状態の悪い患者を対象とすることが多いた め, リスクマネージメントが必要である。今回我々は, まずAmerican Society of Anesthesiologists physical status (ASA-PS) と胆膵内視鏡中の呼吸循環器系合併症の関 与について検討した，介入を要する低血圧，徐脈，低酸素血症を来した症例はASA-PSが 有意に不良であった，全身状態，背景疾患㧍よびASA-PSによる術前の患者評価を行い, 鎮 静薬の投与量を調整する必要性が示唆された. また, 当院で導入した急変時シミュレーショ ンは，多職種が関わることで複数の有効な安全対策を同時に検討・導入することが可能と なり，より安全な胆膵内視鏡診療を構築する機会を得ることができた。十分に計画された 急変時シミュレーションの導入は, 安全·確実な内視鏡診療を進めるうえで有用であり, 今 後，多くの施設での導入が期待される.

〔Key Words〕胆膵内視鏡，急変時シミュレーション，リスクマネージメント

\section{はじめに}

近年，疾病構造の変化もあり，胆膵内視鏡の施 行件数が急速に増加している．基礎疾患の多い高 齢者, 全身状態の不安定な患者に対して胆脺内視 鏡処置を行うことも多いため, リスクマネージメ ントは重要である。胆膵内視鏡は，処置時間や患 者への侵襲性などから, 深い鎮静を要することが 多く, 呼吸循環器系の合併症の危険性が高い ${ }^{1)}$ 。日 本消化器内視鏡学会が集計した2008〜2012年の 5 年間における544施設 1,708 万件中，前処置有害事 象が発生した472件のうち鎮静薬が原因となった ものが219件あり，4例の死亡が報告されている. 記載のある175件の内訳は, 呼吸抑制, 呼吸停止99 例，低酸素血症22例，血圧低下・ショック16例で

\footnotetext{
${ }^{1}$ 慶應義塾大学医学部 /消化器内科, ${ }^{2)}$ 同 $/$ 内視鏡センター, ${ }^{3)}$ 同 一一般消化器外科

*Corresponding author : iwaiwa2007@gmai.com
}

あった ${ }^{2)}$. 前処置の中でも, とくに鎮静剤の潜在的 なリスクの評価が必要と考えられる.

また，以前より内視鏡ユニット ${ }^{3}$ や小览集中治 療4)における急変時シミュレーション (Simulation-based crisis resource management training； SBT)は, 効率のよいチーム医療の構築 や，医療過誤を予防するという点で高い有用性が 報告されている。

当院での胆膵内視鏡における現状と, SBT導入 を含めたリスクマネージメントの取り組みについ て検討し，それぞれ報告する。

I . 胆膵内視鏡処置における呼吸循環器系合併 症についての検討

\section{1. 対象と方法}

2016年 4 月から 2017 年 3 月までに，当施設にお いてERCP関連処置を行った症例について，呼吸 
循環器系合併症の発生頻度と処置 完遂の可否，患者背景因子を検査 レポートおよび診療録から後方視 的に検討した。

当院での胆膵内視鏡における鎮 静と術中モニタリングの方法は, ガイドライン ${ }^{5)}$ に沿い, 開始時にフ ルニトラゼパム $0.2 \mathrm{mg}$ とペチジン 35mgを静脈注射するが, Ramsey 鎮静スコア ${ }^{6}$ の 3 (命令にのみ反応, 眉間の吒打や大きい声に反応す る)〜 4(眠っているが刺激に対し てはっきり反応する)を目指して 適宜増減している。また, 酸素は 経鼻カヌラ $2 \mathrm{~L} / \mathrm{min}$ 投与とし，血 圧測定, $\mathrm{SpO}_{2}$ モニタリングに加 え, 基礎疾患のある患者では, 心 電図モニ夕を装着している。不穏 や体動予防に固定具のイージー フィックス (テウンメディカル, 韓 国)を使用しており, 適宜フルニト ラゼパムの追加で対応している。

治療介入を要する呼吸循環器系 合併症 (バイタル変化)の定義は, 低酸素血症 (酸素 $2.0 \mathrm{~L} / \mathrm{min}$ での $\mathrm{SpO}_{2} 80 \%$ 以下), 低血圧 (収縮期血 圧70mmHg以下), 徐脈(脈拍40/ min以下)とした。 また, American Society of Anesthesiologists physical status (ASA-PS) 分類 ${ }^{7)}$ を評価し, 当院での治療介入の要 否にて比較した。

\section{2. 結果}

対象期間のERCP関連処置は 712 例であり，そのうち26例 (3.7 \%)に治療介入を要するバイタル 変化があった，そのうち，対処後に処置を続行で きたのは21例， 2 例はいったん処置を中止し，内 視鏡抜去後に再試行，3 例は中止されており，術 中死亡はなかった (Fig. 1). ERCP関連処置患者全 体とバイタル変化を来した群とを比較すると, 年 齢 $(68.5 \pm 13.8$ vs. $71.1 \pm 14.5, p=0.28)$ ，夜間時間 外の施行 $(11.6 \%$ vs. $13.0 \%, p=0.84)$ と有意差を認

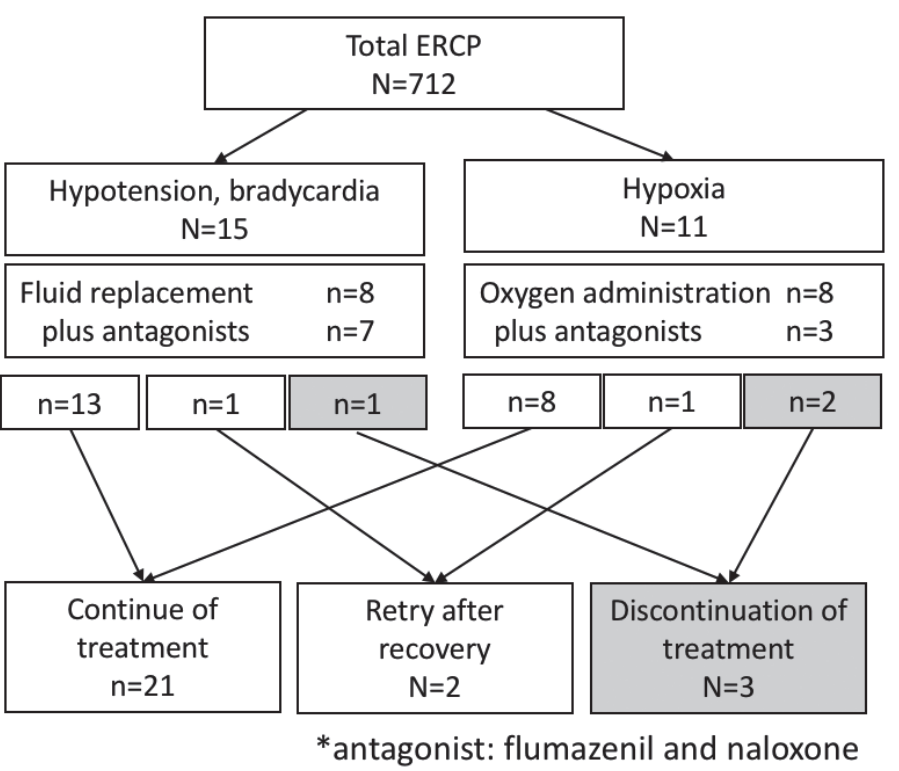

Fig. 1 Chart of the patients with vital change requiring intervention.

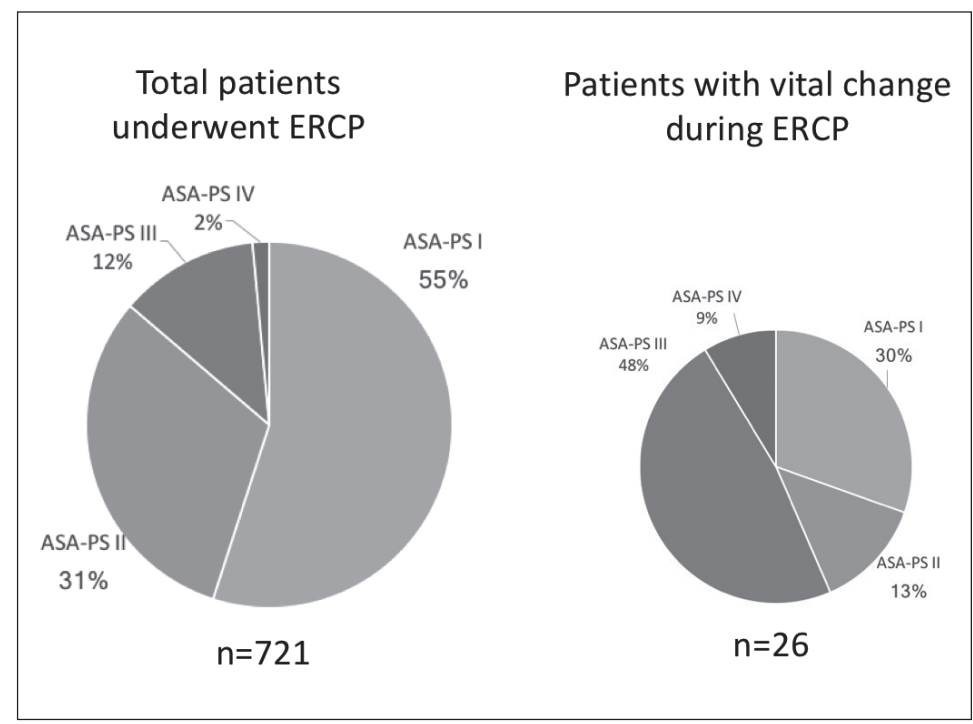

Fig. 2 ASA-PS of patients undergone ERCP related procedure. 


\section{II. 急変時シミュレーション (SBT)の導入と運 用についての検討}

\section{1. 対象と目的}

内視鏡施行時に呼吸循環器系合併症を来した患 者を対象として, 平成25年より内視鏡センターが 主体となってSBTを開始した，主に，急変のリス クが高いと予測された気管支鏡(呼吸器内科・呼吸 器外科), 胆膵内視鏡 (消化器内科 - 消化器外科), $\mathrm{ESD}$ ・低侵襲治療 (腫瘍センター) といった, 内視 鏡治療グループごとに順次導入したので，その運 用と実際について評価した。シミュレーション導 入の具体的な目的は以下のように設定した。1) 患者急変時には検查室内の限られた人員がそれぞ れ確実に役割を遂行することで患者救命率を上げ ること，2) 医師や看護師のみならず，放射線技 師, 看護助手や事務職員までを対象とし, 職種を 超えてセンター全体で取り組むことで，チーム連 携を強化すること， 3 ) 人員を割くべき急変対応 時においても, 他の検查室では引き続き必要な検 查・処置体制が維持できる組織と体制づくり.

\section{2. 事前準備}

ロールプレイを用いたSBTを導入したので，そ の運用について紹介する，患者急変時には，実際 の内視鏡室の人員配置のなかで, 遅滞なく対処す ることが必要であり, 参加者は内視鏡センタース タッフ (医師, 看護師, 放射線技師, 看護助手, 事 務職員), 各内視鏡治療グループ医師全員と, コー ディネーター(当院では内視鏡センター看護ス タッフ), アシスタント 1 2 名(各グループ医師) としている。開催期日は土曜日あるいは業務終了 後の夕方に約 1 時間とし, 各治療グループでそれ ぞれ半年 1 回の開催を目標としている. 開催に合 わせて内視鏡室の確保, シミュレーター(レサシア ンシミュレーター, レールダールメディカルジャ パン, 東京)の手配準備を行ない, 実際に内視鏡な どの配置は通常の治療に準じて準備する.

なお，各検查室内でモニ夕管理しているが，急 変時の対応のためにスタッフステーションにセン トラルモニタを抄き, 観察可能な状態とし, 必要 時に内視鏡センター責任医，リーダースタッフに よるバックアップを行う体制となっている (Color 1)。また, 内視鏡透視室には救急カートが 常備されている.
コーデイネーターとアシスタントは事前にシナ リオを考え，詳細な内容を決定する，想定する病 状は基本的には「内視鏡施行中の呼吸循環器系の 急変」としながら, シチュエーションや人員配置 などを適宜変える工夫をしている．

\section{SBT当日の流れ}

開始時に, コーディネーターより参加者全員に 当日のシナリオと狙いについて提示する. 通常の 人員 (施行医 1 名, 介助医 1 名, 外回り医 1 名, 看 護師 1 名, 放射線技師 1 名) で処置を開始 (Color 1)し, 内視鏡責任医, リーダースタッフはスタッ フステーションで待機とする.残りの医師, スタッ フは周囲から観察としている.コーデイネーター が患者の病状やバイタル読み上げ(あるいはシ ミュレーターを用いてバイタルを変化させる).ア シスタントはSBTの状況を動画で撮影し, 内視鏡 チームは実際に急変時の対処を進めていく (Color 2). 㧍もに2つのポイントからSBTを評価 しており，一点は内視鏡室という状況における急 変初期のマネージメントであり,もう一点は有効 な救命処置である.

急変時初期対応：内視鏡室という特殊性もあり, 鎮静の拮抗, 内視鏡抜去, 体位変換 (特にERCPの) 場合は腹臥位が多い), 透視機器や内視鏡タワーの 移動と同時に, 速やかにかつ並行して救命処置を 開始することが求められる.また, 透視室はスタッ フステーションからは離れているため,「人手を集 める」必要がある。内規に則り, 内視鏡室全体へ 患者急変のアナウンスを入れることで，責任医師 とリーダースタッフ,手の開いている医師・スタッ フが当該内視鏡室へ集合する。責任医師とリー ダースタッフは院内救急コールの判断, あるいは ICUへの搬入を含めた連絡の指示, 内視鏡セン ター全体の処置が滞りなく進むように全体の統括 に務める。

救命処置シミュレーション：責任医による全体 の統括の進行と同時に, 内視鏡室内では引き続き ACLSと同様の急変時の救命トレーニングに移行 する. 救命処置のリーダーの決定, 現状の把握を しながら有効な救命処置を遅滞なく開始する.救 急カート, 処置具も通常急変ど扔りに準備して使 用し, シミュレーターの病態が安定, ICUへの搬 出まで行い終了とする. 
SBT後の検討 : 参加者全員で話し合い, 改善点 を探り，最終的にレポートを作成し今後の改善に つなげ，内視鏡連絡会で今後の改善点を話し合う。

\section{SBT後の症例検討}

SBTによる成果として, 救急時の手順の共有化 を図ることが可能となった。また，内視鏡室に備 えるべき必要な救命処置用品や備品の改善を図る ことができた。また，施行時のリスク判断が重要 であることが再認識され，患者の基礎疾患や使用 薬剤について共有する夕イムアウトも同時期より 導入した。

SBT導入後に経験した症例として，80歳代の男 性がERCP処置開始直後に過鎮静によると思われ る呼吸停止から低酸素血症, 心肺停止に至った. 検 査担当医師や内視鏡センター責任医，看護師らの 連携が円滑になされ，素早い対処と救命処置によ り 5 分ほどで蘇生し, 抻管, ルートキープ, 薬剤 投与を経て，発症より30分以内にICUへ搬入され た. 後日, 後遺症なく軽快・退院されている. 事 前のSBTが生かされ, 現場での統率も取れてお り，事後検討でもべストの対応ができたと考えて いる，その一方で，本症例は透析中の慢性腎臟病 の高齢患者とハイリスクであったにもかかわらず, 前回投与した鎮静剂の量を漫然と投与したことが 反省点であり, 患者の状態に応じて適切な分量を 投与する取り決めを行った。

\section{III. おわりに}

胆膵内視鏡において，治療介入を要するバイ夕 ル変化は一定の割合で認められ，とくに全身状態
や背景疾患のある症例では発現頻度が高い，その ため, タイムアウトを活用して, 鎮静剤の減量を 含めてリスク管理を十分行う必要がある。

また，多職種が関わり開催するSBTにより，複 数の有効な安全対策を検討・導入することが可能 となり,より安全な胆膵内視鏡診療を構築する機 会を得ることができた，実際のSBTの運用，SBT 中の評価方法の標準化，SBT導入による効率的な チーム運用やリスク低減に関する評価指標がまだ 不十分ではあるが，十分に計画されたSBTの導入 は，安全・確実な内視鏡診療を進めるうえで有用 であり，今後，多くの施設で導入されることが期 待される.

文 献

1 ) Amornyotin $\mathrm{S}:$ Sedation and monitoring for gastrointestinal endoscopy. World J Gastrointest Endosc 5 : 47-55, 2013

2 ) 古田隆久, 加藤元嗣, 伊藤透他 消化器内視鏡関連の偶発症 に関する第 6 回全国調查報告一2008年～2012年までの 5 年 間. Gastroenterol Endosc 58 : 1466-1491, 2016

3 ) Heard LA, Fredette ME, Atmadja ML, et a ; 1 . Perceptions of simulation-based training in crisis resource management in the endoscopy unit. Gastroenterol Nurs $34: 42-48$, 2011

4) Cheng A, Donoghue A, Glifoyle E, et al : Simulation-based crisis resource management training for pediatric critical care medicine : a review for instructors. Pediatr Criti Care Med $13: 197-203,2012$

5 ）小原勝敏，春間 賢，入澤篤志，他. 内視鏡診療における鎮 静に関するガイドライン Gastroenterol Endosc 55 : 38223847,2013

6 ) Ramsay MA, Savege TM, Simpson BR, et al : Controlled sedation with alphaxalone-alphadolone. Br Med J 2 : 656659, 1974

7 ）ASA分類： https://www.asahq.org 〈カラーはp.3に掲載〉 


\section{Risk management for cardiorespiratory complication during ERCP treatment}

$\begin{array}{ll}\text { Eisuke Iwasaki }^{1 * *} & \text { Seiichiro Fukuhara } \\ \text { Youichi Takimoto }^{1)} & \text { Hiroki Tamakawa } \\ \text { Shintaro Kawasaki }^{1)} & \text { Takashi Seino } \\ \text { Naoki Hosoe }^{\text {() }} & \text { Minoru Kitago }\end{array}$

We sometimes experience an acute cardiorespiratory complication such as hypotension, bradycardia, hypoxia or cardiac arrest during ERCP treatment under deep sedation. The incidence is known to be high especially in patients with comorbid diseases. We first evaluated the relationship during American Society of Anesthesiologists physical status (ASAPS) and cardiorespiratory complication in our institution. The ASA-PS classification was significantly higher in the patients with a cardiorespiratory vital change requiring intervention during ERCP compared to the control. Therefore, it is necessary to check the underlying disease of the patient at timeout, and to decide the dose of sedative agent according to patient's condition. Secondary, we evaluated an introduction of a simulation-based crisis resource

\author{
Takahiro Matsunaga ${ }^{1)}$ \\ Yujiro Machida ${ }^{1}$ \\ Tadashi Katayama ${ }^{1)}$ \\ Kazuhiro Minami ${ }^{1)}$ \\ Misako Matsushita ${ }^{1)}$ \\ Masayasu Horibe ${ }^{1)}$ \\ Haruhiko Ogata ${ }^{2}$
}

management training (SBT) for endoscopic unit, under cooperation of many medical professions. We successfully construct a safer ERCP examination based on the experience of SBT, by discussing multiple effective safety managements. However, standardization and evaluation of SBT has not been still sufficient, and further study is required. The carefully planned SBT was useful for promoting safe and reliable endoscopic examination, and is expected to be introduced in many facilities in the future.

1) Division of Gastroenterology and Hepatology, Department of Internal Medicine. ${ }^{2)}$ Center for Diagnostic and Therapeutic Endoscopy. ${ }^{3)}$ Department of Surgery, Keio University School of Medicine

*Corresponding author : iwaiwa2007@gmai.com 